\title{
Meclocycline Sulfosalicylate
}

National Cancer Institute

\section{Source}

National Cancer Institute. Meclocycline Sulfosalicylate. NCI Thesaurus. Code C47596.

The sulfosalicylate salt form of meclocycline, a tetracycline antibiotic with broadspectrum antibacterial and antiprotozoal activity. Meclocycline sulfosalicylate is bacteriostatic and inhibits bacterial protein synthesis by binding to the $30 \mathrm{~S}$ ribosomal subunit, thereby preventing the addition of amino acids to the growing peptide chain. This tetracycline is active against a wide range of gram-positive and gram-negative bacteria. 